\title{
Grouping of regions on the basis of grassland vegetation
}

\author{
TH. A. DE BOER
}

Research and Advisory Institute for Field Crops and Grassland Husbandry, Wageningen, Netherlands

\section{Summary}

This article gives an example of the classification of regions into groups based on the results of grassland-vegetation maps. The classification is done in such a way as to bring out the agronomic problems of each group.

During the last 12 years detailed vegetation surveys have been made in the Netherlands of c. 150,000 ha and rough surveys of c. 22,000 ha. The results were mapped and are used in planning improvement schemes for entire regions.

These grassland-vegetation maps show the present situation of the productivity and quality of grassland. Information is also given on such habitat factors as water supply and management status that determine the agronomic value of grassland.

Every vegetation unit (DE BOER, 1963a) has an average "use value", viz. a relative figure which is closely correlated to the starch-equivalent production per ha.

By measuring the area covered by the various vegetation units and multiplying by the relative figures, the total improvement possibilities can be calculated and compared with the cost. The influence of the improvement of the water supply or the sward can be separately valuated (DE BOER, 1963 b).

At the moment data is available on more than 50 regions and it will be interesting to compare them. Each region comprises a number of entire farms.

As there are only slight differences in climate in the Netherlands, the soil in situ is the regulator of the water supply. The soil factors regulating the water supply are: a. average trend of the ground-water table, b. permeability, c. water capacity, d. capillarity. This group of factors together determines the agricultural value of the grassland.

Water excess will be discussed as the first grouping principle, because under Dutch climate and soil conditions water excess is a very important factor and expensive to improve. For the sake of simplicity the different classes of "wet grassland" of the detailed map are combined in one class of "too wet" grassland. All grassland with $5 \%$ or more of plant species indicating wet conditions belongs to this class (KRUIJNE and DE VRIES, 1963). For further details on the classification of vegetation units readers are referred to an earlier publication (DE BOER, 1956). As the percentage of "wet indicators" increases, the following disadvantages also increase in severity; depression of grass growth in spring or at other times of the season with low temperatures (DE BOER, 1963c) and treading or poaching by cattle in rainy periods. These properties are great obstacles to the intensification of grassland use.

Received for publication 11th February, 1965. 
TH. A. DE BOER

$$
=8+1+11111-
$$

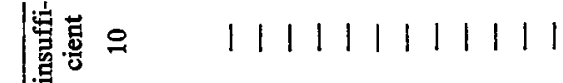

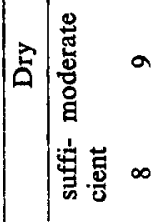

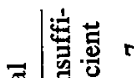

氶

z

落

象

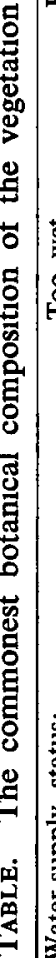




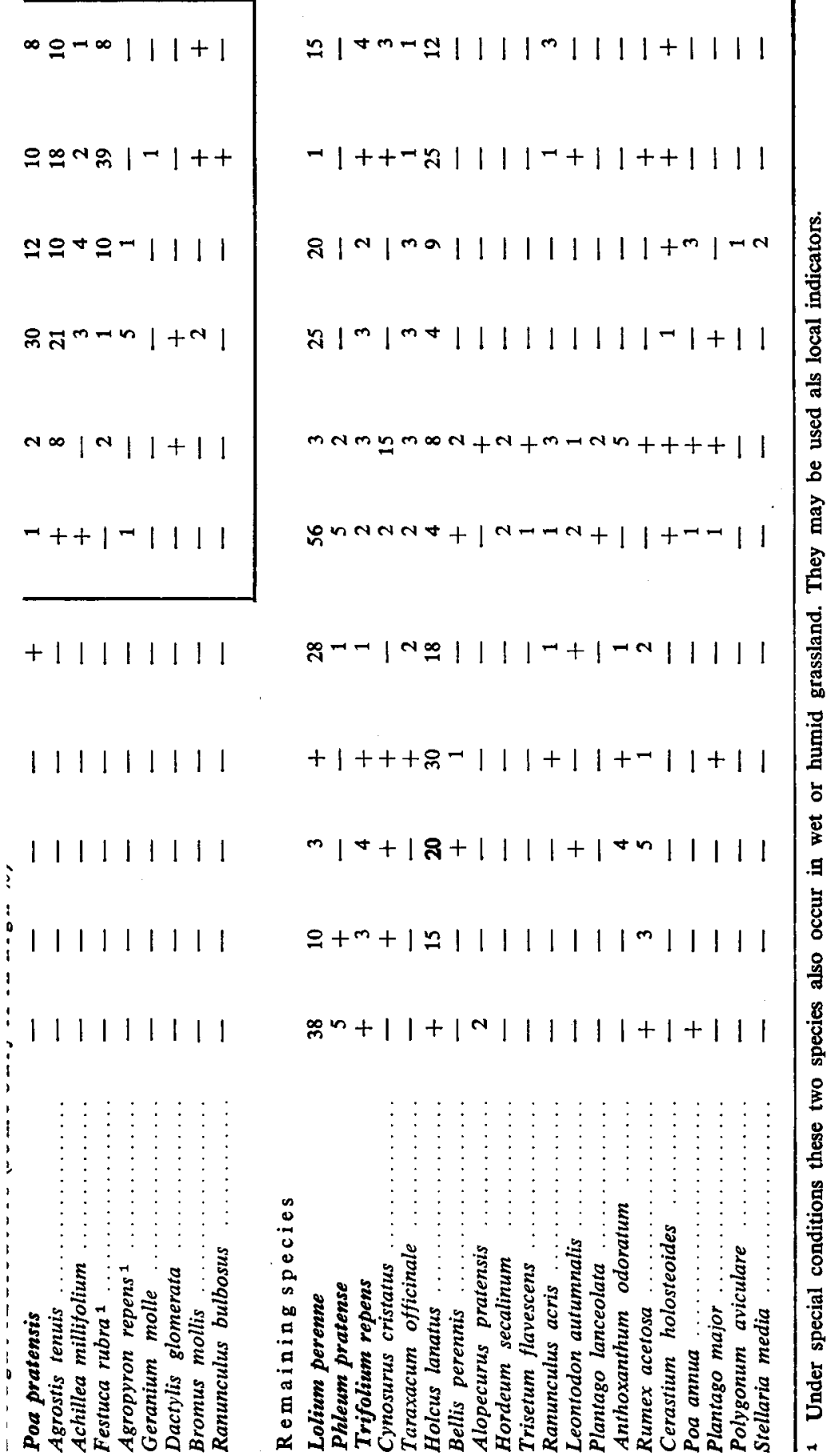


The mapping districts denoting $40 \%$ or more "too wet" grassland are situated in all parts of the Netherlands. The peat and clay on peat regions in the west of the Netherlands (a very flat area) belong to this group. In addition to the high percentage of "too wet" grassland, it has a high percentage of "humid" grassland with less than $5 \%$ of "wet indicators". Generally, $80 \%$ or more of this area belongs to these two classes, so that there are many water-excess problems in this type of district. Management in these purely grassland districts is as good as possible under the prevailing conditions. There is therefore a high percentage of the group of plant species indicating a high management status of the sward (KRUIJNE and DE VRIES, 1963) (see the species in bold print in the TABLE). In this TABLE, the numbers 1,2 and 5 show records of the botanical composition of three fields, characteristic of these peat districts. A striking feature is the high percentage of Poa trivialis, indicating a high fertilization status on wet and humid grassland (No. 1 and 5).

Mapping districts with the water-excess aspect are also situated along the south coast of the former Zuiderzee. The soil profile is somewhat different. The management status of the sward is lower, resulting in a higher percentage of undesirable plant species (DE VRIES, DE BOER and DIRVEN, 1949), as Holcus lanatus and Agrostis stolonifera. No. 3 is a good example of this type of vegetation, which is found on wide areas of grassland in these districts.

Some mapping districts belonging to the above-mentioned group comprising over $40 \%$ of "too wet" grassland are found in the sandy districts in the north-east of the Netherlands. A feature of the "too wet" grassland in these regions is the variable, but sometimes very high percentage of Deschampsia cespitosa (No. 4). Another remarkable feature is the much lower percentage of "humid" grassland and a fairly high percentage of "dry" and "very dry" grassland. During rainy periods the farmers in these districts may graze their cattle on the drier soils which have a greater carrying capacity. The landscape of these districts includes both brook valleys and wind-blown higher loamy sand and sand areas.

Another group of mapping districts is distinguished by its wide areas of grassland without "wet indicators" and a low percentage of "drought indicators" only. This grassland is assumed to have a "sufficient" or "normal" water supply. The carrying capacity of these grasslands is always good and compensates the slight growth depression in dry summer periods.

There are five districts belonging to this group with over $40 \%$ of grassland in this water-supply class. The soil in these districts usually consists entirely of river or sea clay. Potentially these are the best districts and some of them have the highest average "use value". This value is calculated for every mapping district and permits ready comparison with other districts. The few districts with a high average "use value" have a high percentage of grassland with a superior botanical composition (DE VRIEs, De Boer and Dirven, 1949), as demonstrated by No. 6 (see the species in bold print).

Some of the river-clay districts of the group show a much lower average "use value", caused by a higher percentage of poorly managed grassland. As a result there is more grassland with a lower botanical quality (No. 7).

Four other mapping districts, showing a lower percentage of grassland with "normal water supply", reach the highest average "use value" class. These are the sea-clay and loamy-sand districts. "Humid" and "somewhat dry" grassland together with "normal water supply" cover a very high proportion of the districts concerned. Although the spread around the agriculturally optimal water supply is somewhat greater, it still 
permits good management.

A different group of districts has over $40 \%$ of "dry" grassland. There are only three of these districts, totalling 7500 ha. All are situated in the sandy district of the north-east and consist of wind-blown sand, sometimes with boulder clay at various depths in the profile. No. 8 shows the botanical composition of a well-managed, dry field and No. 10 that of a poorly-managed, dry field.

If the boulder clay is high in the profile, say about $30 \mathrm{~cm}$, the water supply may show extreme fluctuations. No. 11 is an example of the botanical composition on this profile.

Thus the percentage of grassland with a "fluctuating water supply" enables a subclassification to be made in the "dry" districts.

On the well-managed "dry" grasslands in the north-east Netherlands Poa pratensis is much more frequent than in the sandy districts of the south. The relatively severer winter in the north-east may be a factor in this concern. The same dominance communities are found in Scandinavia and some mountain regions of Europe.

In highly-stocked, drier grassland and with heavy nitrogen dressings, a fairly high percentage of Agropyron repens may often be found as well (No. 9). If grazed in a young condition or with zero grazing, the per ha animal production will be reasonably high.

More determinations are possible with different combinations of area percentages in the various "water-supply classes" and "management classes".

BoER, TH. A. DE

Kruine, A. A., and D. M. DE VRIES

VRIES, D. M. DE, TH. A. DE BOER and J. G. P. Dirven

\section{REFERENCES}

1956 Een globale graslandvegetatiekartering van Nederland. Versl. Landbk. Onderz. No. 62 (5) 1-69.

1963a Agronomic evaluation of grassland on the basis of the botanical composition. In: The Agronomic Evaluation of Grassland. Grassland Research Institute, Hurley. 9-11.

1963b Die Grünlandvegetationskartierung als Grundlage für landwirtschaftliche Verbesserung ganzer Gebiete in den Niederlanden. In: Das Internationale Symposium für Vegetationskartierung. Verlag J. Cramer, Weinheim. 441-455.

1963c Produktion und Jahreszeitliche Produktionsverteilung von Grünlandvegetationseinheiten. In: Die Stoffproduktion der Pflanzendecke. Gustav Fisher Verlag, Stuttgart. 60-68.

1963 Data concerning important herbage plants. Meded. I.B.S. Wageningen. No. 225, 1-45.

1949 Evaluation of grassland by botanical research in the Netherlands. Proc. United Nations Sci. Conf. Cons. Utiliz. Resourc. U.S.A. 6, 552-524. 